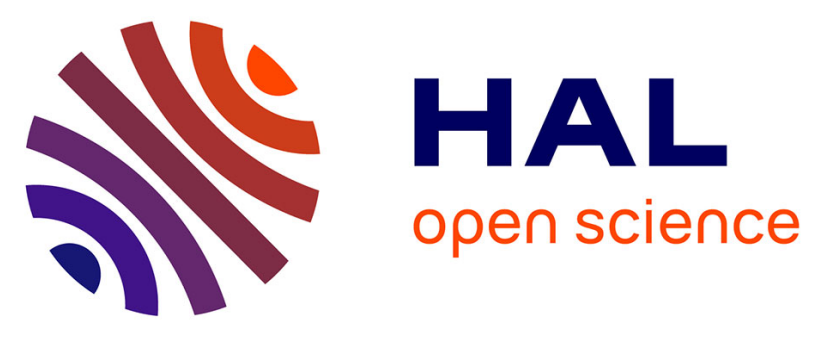

\title{
Carbon isotopic signature of CO2 emitted by plant compartments and soil in two temperate deciduous forests
}

Florence F. Maunoury-Danger, Nicolas Chemidlin Prévost-Bouré, Jérome J.

Ngao, Daniel D. Berveiller, Claude C. Brechet, Eric E. Dufrene, Daniel D.

Epron, Jean Christophe J. C. Lata, Bernard B. Longdoz, Caroline C.

Lelarge-Trouverie, et al.

\section{- To cite this version:}

Florence F. Maunoury-Danger, Nicolas Chemidlin Prévost-Bouré, Jérome J. Ngao, Daniel D. Berveiller, Claude C. Brechet, et al.. Carbon isotopic signature of $\mathrm{CO} 2$ emitted by plant compartments and soil in two temperate deciduous forests. Annals of Forest Science, 2013, 70 (2), pp.173-183. 10.1007/s13595-012-0249-5 . hal-00964701

\section{HAL Id: hal-00964701 \\ https://hal.science/hal-00964701}

Submitted on 29 May 2020

HAL is a multi-disciplinary open access archive for the deposit and dissemination of scientific research documents, whether they are published or not. The documents may come from teaching and research institutions in France or abroad, or from public or private research centers.
L'archive ouverte pluridisciplinaire HAL, est destinée au dépôt et à la diffusion de documents scientifiques de niveau recherche, publiés ou non, émanant des établissements d'enseignement et de recherche français ou étrangers, des laboratoires publics ou privés.

$$
\text { Copyright }
$$




\title{
Carbon isotopic signature of $\mathrm{CO}_{2}$ emitted by plant compartments and soil in two temperate deciduous forests
}

\author{
Florence Maunoury-Danger • Nicolas Chemidlin Prevost Boure • \\ Jérôme Ngao • Daniel Berveiller • Claude Brechet • Eric Dufrene • Daniel Epron • \\ Jean-Christophe Lata $\cdot$ Bernard Longdoz $\cdot$ Caroline Lelarge-Trouverie • \\ Jean-Yves Pontailler • Kamel Soudani • Claire Damesin
}

Received: 28 July 2012 / Accepted: 29 October 2012 / Published online: 15 November 2012

(C) INRA and Springer-Verlag France 2012

\begin{abstract}
- Context The carbon isotope composition of the $\mathrm{CO}_{2}$ efflux $\left(\delta^{13} C_{E}\right)$ from ecosystem components is widely used to investigate carbon cycles and budgets at different ecosystem scales. $\delta^{13} \mathrm{C}_{\mathrm{E}}$, was considered constant but is now known to
\end{abstract}

Handling Editor: Erwin Dreyer

Contribution of the co-authors Florence Maunoury-Danger Nicolas Chemidlin Prevost Boure, Jérôme Ngao, Daniel Berveiller, Claude Brechet, Eric Dufrene, Daniel Epron, Jean-Christophe Lata, Bernard Longdoz, Caroline Lelarge Trouverie, Jean-Yves Pontailler, Kamel Soudani, Claire Damesin: performing practical work, field sampling, phenological and climatic measurements and isotopic analysis from Barbeau and Hesse sites.

Florence Maunoury-Danger Nicolas Chemidlin Prevost Boure, Jérôme Ngao, Bernard Longdoz, Daniel Epron, Claire Damesin: data analyses Claire Damesin: designing the experiment and coordinating the research projects 'Ministère délégué à la recherche-ACI Jeunes Chercheurs' (no. JC10009) and 'Programme National ACI/FNS ECCO PNBC' (convention no. 0429 FNS)

Florence Maunoury-Danger: writing the paper

F. Maunoury-Danger $(\bowtie) \cdot N$. Chemidlin Prevost Boure •

K. Soudani $\cdot$ C. Damesin

AgroPariTech, Ecologie Systématique et Evolution,

UMR 8079, CNRS, Univ. Paris-Sud,

Orsay 91405, France

e-mail: florence.maunoury-danger@univ-lorraine.fr

D. Berveiller $\cdot$ E. Dufrene $\cdot$ J.-Y. Pontailler

CNRS, UMR 8079, Ecologie Systématique et Evolution,

Orsay 91405 , France

J. Ngao $\cdot$ C. Brechet $\cdot$ B. Longdoz

INRA, Écologie et Écophysiologie Forestières, UMR 1137,

Champenoux 54280, France

D. Epron

Écologie et Écophysiologie Forestières, UMR 1137,

Université de Lorraine,

Vandoeuvre 54506, France vary along seasons. The seasonal variations have rarely been compared among different ecosystem components.

- Aims We aimed to characterise simultaneously the seasonal dynamics of $\delta^{13} \mathrm{C}_{\mathrm{E}}$ in different compartments of two temperate broadleaved forest ecosystems.
J.-C. Lata

UMR 7618, Ecole Normale Supérieure, UPMC-Bioemco,

46 Rue d'Ulm,

75230 Paris Cedex 05, France

C. Lelarge-Trouverie

UMR 8618, Institut de Biotechnologie des Plantes,

Univ. Paris-Sud,

Orsay 91405, France

Present Address:

F. Maunoury-Danger

Université de Lorraine, LIEBE, CNRS, UMR 7146,

Metz 57070, France

Present Address:

J. Ngao

INRA, Clermont Université Blaise Pascal, UMR 547 PIAF,

63100 Clermont-Ferrand, France 
- Methods Using manual chambers and isotope ratio mass spectrometry, we recorded simultaneously $\delta^{13} \mathrm{C}_{\mathrm{E}}$ and $\delta^{13} \mathrm{C}$ of organic matter in sun leaves, current-year twigs, trunk bases and soil in an oak and a beech forest during 1 year.

- Results In the two forests, $\delta^{13} C_{E}$ displayed a larger variability in the tree components than in the soil. During the leafy period, a pronounced vertical zonation of $\delta^{13} \mathrm{C}_{\mathrm{E}}$ was observed between the top (sun leaves and twigs with higher values) and bottom (trunk and soil with lower values) of the ecosystem. No correlation was found between $\delta^{13} \mathrm{C}_{\mathrm{E}}$ and $\delta^{13} \mathrm{C}$ of organic matter. Causes for these seasonal variations and the vertical zonation in isotope signature are discussed. - Conclusion Our study shows clear differences in values as well as seasonal dynamics of $\delta^{13} \mathrm{C}_{\mathrm{E}}$ among different components in the two ecosystems. The temporal and local variation of $\delta^{13} \mathrm{C}_{\mathrm{E}}$ cannot be inferred from organic matter signature or $\mathrm{CO}_{2}$ emission rates.

Keywords Carbon isotopic composition $\cdot \mathrm{CO}_{2}$ efflux $\cdot$ Oak forest $\cdot$ Beech forest

\begin{tabular}{|c|c|}
\hline \multicolumn{2}{|c|}{ Abbreviations } \\
\hline$E_{\mathrm{T}}$ & Trunk $\mathrm{CO}_{2}$ efflux \\
\hline$E_{\mathrm{S}}$ & Soil $\mathrm{CO}_{2}$ efflux \\
\hline$E_{\mathrm{ECO}}$ & Ecosystem $\mathrm{CO}_{2}$ efflux \\
\hline$\delta^{13} \mathrm{C}$ & Carbon isotope composition \\
\hline$\delta^{13} \mathrm{C}_{\mathrm{E}}$ & Carbon isotope composition of $\mathrm{CO}_{2}$ efflux \\
\hline$\delta^{13} \mathrm{C}_{\mathrm{EECO}}$ & $\delta^{13} C_{E}$ of ecosystem \\
\hline$\delta^{13} \mathrm{C}_{\mathrm{EL}}$ & $\delta^{13} C_{E}$ of leaves \\
\hline$\delta^{13} \mathrm{C}_{\mathrm{ETG}}$ & $\delta^{13} \mathrm{C}_{\mathrm{E}}$ of twigs \\
\hline$\delta^{13} \mathrm{C}_{\mathrm{ET}}$ & $\delta^{13} C_{E}$ of trunk \\
\hline$\delta^{13} \mathrm{C}_{\mathrm{ES}}$ & $\delta^{13} \mathrm{C}_{\mathrm{E}}$ of soil \\
\hline$\delta^{13} \mathrm{C}_{\mathrm{OM}}$ & $\delta^{13} \mathrm{C}$ of total organic matter \\
\hline$\delta^{13} \mathrm{C}_{\mathrm{OM}}$ & $\delta^{13} \mathrm{C}_{\mathrm{OM}}$ of leaf \\
\hline$\delta^{13} \mathrm{C}_{\mathrm{OMT}}$ & $\delta^{13} \mathrm{C}_{\mathrm{OM}}$ of twig \\
\hline$\delta^{13} \mathrm{C}_{\mathrm{OMT}}$ & $\delta^{13} \mathrm{C}_{\mathrm{OM}}$ of trunk \\
\hline$\delta^{13} \mathrm{C}_{\mathrm{OMS}}$ & $\delta^{13} \mathrm{C}$ of soil total organic matter \\
\hline Doy & Day of year \\
\hline
\end{tabular}

\section{Introduction}

The carbon isotope composition $\left(\delta^{13} \mathrm{C}\right)$ of $\mathrm{CO}_{2}$ is now commonly used at the ecosystem level as a natural tracer to investigate carbon processes and their responses to environmental conditions. Approaches coupling isotopic and mass balance are used to partition ecosystem $\mathrm{CO}_{2}$ efflux $\left(E_{\mathrm{ECO}}\right)$ and photosynthetic fluxes (Zobitz et al. 2007). The $\delta^{13} \mathrm{C}$ of $E_{\mathrm{ECO}}\left(\delta^{13} \mathrm{C}_{\mathrm{EECO}}\right)$ is used to infer ecosystem or regional $\mathrm{C}$ sink strength by inversion modelling. Large uncertainties are remaining about the interpretation of $\delta^{13} \mathrm{C}_{\mathrm{EECO}}$, mainly due to the multi-source nature of $\mathrm{E}_{\mathrm{ECO}}$, and the temporal variability of $\delta^{13} \mathrm{C}$ values of $\mathrm{E}_{\mathrm{ECO}}$ components and their contributions to $E_{\mathrm{ECO}}$ (Bowling et al. 2002; Hemming et al. 2005). Until recently, $\delta^{13} C_{E}$ values used to interpret $\delta^{13} \mathrm{C}_{\mathrm{EECO}}$ were considered to be similar among different ecosystem components (i.e., soil, roots, trunk, twigs and leaves) (Kodama et al. 2008).

So far, few studies have examined $\delta^{13} C_{E}$ of several components concurrently: between leaf and soil (Mortazavi et al. 2005), trunk and soil (Kodama et al. 2008) or different plant organs (Eglin et al. 2009; Kuptz et al. 2011); they showed significant differences in $\delta^{13} \mathrm{C}_{\mathrm{E}}$ among the targeted components. Moreover, the $\delta^{13} \mathrm{C}_{\mathrm{E}}$ for a given component can exhibit a high seasonal or diurnal variability, up to $10 \%$ for leaves (Hymus et al. 2005; Prater et al. 2005), 4\%o for twigs (Damesin and Lelarge 2003), 3-5.5\% for trunks (Maunoury et al. 2007; Ubierna et al. 2009) and 4.2\% for soil (Ngao et al. 2005, Marron et al. 2009). However, only a few of these studies included wintertime measurements (Damesin and Lelarge 2003; Maunoury et al. 2007; Kuptz et al. 2011).

Seasonal variations in $\delta^{13} C_{E}$ have been related to several factors such as environmental conditions several days before measurements (Bowling et al. 2002; Ekblad et al. 2005), canopy stomatal conductance (Mc Dowell et al. 2004), the nature and/or $\delta^{13} \mathrm{C}$ of respiratory substrates (Damesin and Lelarge 2003; Kuptz et al. 2011) or to other metabolic processes, such as variations in respiratory pathways (Tcherkez et al. 2003; Kuptz et al. 2011). Recently, a comprehensive study concluded that seasonal $\delta^{13} C_{E}$ patterns in one ecosystem were similar for the different components of beech and spruce and between both species (Kuptz et al. 2011), also showing maximal differences for the trunk between summer and winter. The question now arising is how recurrent are seasonal patterns (1) for a given species at different environmental conditions and (2) between closely related species depending on leaf phenology.

In this context, we focused on the spatio-temporal $\delta^{13} \mathrm{C}_{\mathrm{E}}$ dynamics of the main tree components (leaves, twigs and trunks) and soil in two temperate broadleaved forest ecosystems. The main objectives of this study were (1) to quantify differences in $\delta^{13} \mathrm{C}_{\mathrm{E}}$ among components and (2) to characterize their seasonal variation, in particular between the two main phenological periods (i.e. leafy and winter period), and their potential link with environmental parameters (air and soil temperature, relative humidity, vapour pressure deficit), $\mathrm{CO}_{2}$ efflux rates and the respective total organic matter $\delta^{13} \mathrm{C}$. Synchronous in situ measurements of $\mathrm{CO}_{2}$ efflux rates and $\delta^{13} \mathrm{C}_{\mathrm{E}}$ were performed throughout 1 year in an oak (Quercus petraea L.) and a beech (Fagus sylvatica L.) forest using isotope mass spectrometry measurements. In order to validate $\mathrm{CO}_{2}$ field-sampling methods adapted to leaf and twig components (Prater et al. 2005; Werner et al. 2007), we compared two methods of tissue incubation, with $\mathrm{CO}_{2}$-free air or $\mathrm{N}_{2}$ flushes usable under field conditions. 


\section{Materials and methods}

\subsection{Study sites and experimental setup}

The study was conducted in two French forest sites belonging to the CARBOEUROPE IP network (http:// www.carboeurope.org/). The Barbeau forest (cluster_FR1, FR-Fon site, $48^{\circ} 29^{\prime} \mathrm{N}, 02^{\circ} 47^{\prime} \mathrm{E}$, Table 1 ) is a managed mature oak-dominated ( $Q$. petraea) stand with an understory of Carpinus betulus L. Soil is a gleyic luvisol [World Reference Base (WRB) classification] of $80 \mathrm{~cm}$ depth, on millstone bedrock and covered with an oligomull humus type, named "Barbeau" in the following. The Hesse forest (cluster_FR1, FR-He site, $48^{\circ} 40^{\prime} \mathrm{N}, 7^{\circ} 05^{\prime} \mathrm{E}$, Table 1), is a young beech-dominated (F. sylvatica) stand with a dystric cambisol (WRB classification) of $120 \mathrm{~cm}$ depth and an oligomull humus type. This site is subsequently named "Hesse".

The study was conducted from March 2005 (before budburst) to January 2006 during nine field campaigns in Barbeau (06/04, 18/04, 02/05, 01/06, 21/06, 11/07, 09/09, $23 / 11$, and 12/01) and four field campaigns in Hesse (16/03, $18 / 05,05 / 07$, and 14/09). Gas exchange measurements, $\mathrm{CO}_{2}$, and organic matter sampling were always performed between 10:00 and 13:00 UT to avoid diurnal variations in $\delta^{13} \mathrm{C}_{\mathrm{E}}$ as previously observed (Maunoury et al. 2007). Each four dominant oak and beech trees were randomly selected for the whole campaign. Soil measurements were performed around the sampled trees, within about $20 \mathrm{~m}^{2}$.

\subsection{Environmental and phenological parameters}

At both sites and for each campaign, soil temperature was measured at $10 \mathrm{~cm}$ depth using a temperature probe (LM35CZ) in Barbeau and five copper-constantan thermocouples (Faculty of Agronomy of Gembloux, Belgium) in Hesse. Soil surface moisture (in the $0-6 \mathrm{~cm}$ layer) was measured using a capacitive ML2x Thetaprobe (Delta- $T$ Device, Cambridge, UK) in Barbeau. Mean air temperature at $2 \mathrm{~m}$ height (sensor LM35CZ), rainfall and air relative humidity (to calculate water vapour pressure deficit, VPD) were determined every $30 \mathrm{~min}$ by meteorological stations installed on-site.

Budburst dates (Table 1) were determined by field observations as either $50 \%$ of trees showing $50 \%$ of bursted buds in Barbeau, or as the beginning increase in the leaf area index (LAI), measured at regular intervals before and during the leafy period (LI-COR LAI 2000) in Hesse. The leaf fall period was also recorded at both sites. The trunk growth period was determined by tape measurements of the radius at $1.30 \mathrm{~m}$ height every week in Barbeau and during each field campaign in Hesse (Table 1). The growing period is defined as the time of trunk growth, while the leafy period includes the time span between bud burst and leaf fall.

\subsection{Trunk and soil $\mathrm{CO}_{2}$ efflux rates}

Trunk $\mathrm{CO}_{2}$ efflux rate $\left(E_{\mathrm{T}}\right)$ was measured using a closed chamber system (see Damesin et al. 2005 for a detailed
Table 1 Stand characteristics for Barbeau and Hesse in 2005

\begin{tabular}{|c|c|c|c|}
\hline $\begin{array}{l}\text { Table } 1 \text { Stand characteristics } \\
\text { for Barbeau and Hesse in } 2005\end{array}$ & \multicolumn{2}{|r|}{ Barbeau (oak forest) } & Hesse (beech forest) \\
\hline & Location & $48^{\circ} 29^{\prime} \mathrm{N}, 02^{\circ} 47^{\prime} \mathrm{E}$ & $48^{\circ} 40^{\prime} \mathrm{N}, 7^{\circ} 05^{\prime} \mathrm{E}$ \\
\hline & Elevation ( $\mathrm{m}$ above sea level) & 90 & 300 \\
\hline & Climate & $\begin{array}{l}\text { Modified temperate maritime } \\
\text { climate }\end{array}$ & Continental climate \\
\hline & Mean annual temperature $\left({ }^{\circ} \mathrm{C}\right)$ & 10.5 & 9.2 \\
\hline & Annual rainfall $(\mathrm{mm})$ & 690 & 820 \\
\hline & Soil type (WRB classification) & Gleyic luvisol & Stagnic luvisol \\
\hline & Humus type & Oligomull & Oligomull \\
\hline & Stand age in 2005 (years) & $100-150$ & 40 \\
\hline & Ground area $\left(\mathrm{m}^{2} \mathrm{ha}^{-1}\right)$ & 20.7 & 25.3 \\
\hline & Tree density (stems ha ${ }^{-1}$ ) & 3480 & 1134 \\
\hline & Max tree height $(\mathrm{m})$ & 30 & 20 \\
\hline & Dominant species & Quercus petraea L. & Fagus sylvatica $\mathrm{L}$. \\
\hline & Understorey & Dense & Sparse \\
\hline & Represented tree species & Carpinus betulus $\mathrm{L}$. & $\begin{array}{l}\text { Quercus petraea L. Betula pendula L. } \\
\text { Carpinus betulus L. }\end{array}$ \\
\hline & Budburst (dominant species) & Doy 110 & Doy 119 \\
\hline & Leaf fall & From doy 287 to 337 & From doy 297 to 310 \\
\hline \multirow{2}{*}{$\begin{array}{l}{ }^{\mathrm{a}} \text { Deduced from the four } \\
\text { dominant trees selected at both } \\
\text { sites }\end{array}$} & Trunk growth ${ }^{\mathrm{a}}$ & Between doy 115 and 239 & Between doy 115 to 214 \\
\hline & Trunk diameter at $1.30 \mathrm{~m}^{\mathrm{a}}(\mathrm{cm})$ & $25-39$ & $24-27$ \\
\hline
\end{tabular}

${ }^{a}$ Deduced from the four dominant trees selected at both sites 
description). Briefly, a cylindrical polymethyl methacrylate (PMMA) chamber was temporarily fixed on the trunk, cleaned of mosses and lichens, with a rubber sealant (Terosta-7, Teroson, Ludwigsburg, Germany) and connected to an infrared gas analyser (IRGA, EGM4, PPSystems, Hitchin, UK). The installation was considered to be leakfree if blowing air along the seals caused no increase in the $\mathrm{CO}_{2}$ level inside the chamber. A fan provided air mixing within the chamber. Once tightly fixed to the trunk, the chamber was purged from accumulated $\mathrm{CO}_{2}$ by opening a 5 -cm diameter lid. Once back to ambient $\mathrm{CO}_{2}$ concentrations, the lid was closed to allow $\mathrm{CO}_{2}$ accumulation. Three to four $E_{\mathrm{T}}$ measurements of 2 min during linear $\mathrm{CO}_{2}$ increase were performed each time. The $E_{\mathrm{T}}$ values were determined from the slope of $\mathrm{CO}_{2}$ concentration increase and expressed per unit volume of living tissue (i.e., phloem and sapwood; in $\mu \mathrm{molm}^{-3}$ living tissue $\mathrm{s}^{-1}$ ). For beech, the whole trunk volume was considered because living cells occur all along the trunk radius (Ceschia et al. 2002). For each oak tree, the living tissue cross-section was determined from a trunk core collected near the chamber at the end of the campaign. The chambers were reinstalled at the same place during each campaign.

Soil $\mathrm{CO}_{2}$ efflux $\left(E_{\mathrm{S}}\right)$ was measured using two different closed dynamic systems (Ngao et al. 2006; Chemidlin Prévost-Bouré et al. 2009): In Barbeau, an EGM4 was connected to a homemade PMMA chamber $(25.4 \mathrm{~L}$, $12 \mathrm{~cm}$ height), while in Hesse, a Li-6200 (LI-COR Inc., Lincoln, NE, USA) IRGA was used with the Li-6000-9 chamber. In both cases, the soil chamber was put on collars previously inserted into the soil under the canopy (500 and $110 \mathrm{~mm}$ diameter in Barbeau and Hesse respectively, inserted 2-3 cm deep) at the beginning of the year, allowing measurements at the same place during field sessions. Two collars were installed at Barbeau and three at Hesse. $E_{\mathrm{S}}$ values were calculated from the slope of $\mathrm{CO}_{2}$ increase and expressed per surface area (in $\mu \mathrm{molm}^{-2}$ soils $^{-1}$ ).

\section{$2.4 \mathrm{CO}_{2}$ sampling for isotopic analysis}

\subsubsection{Incubation tests}

The gaseous medium $\left(\mathrm{N}_{2}\right.$ vs. $\mathrm{CO}_{2}$-free air) of an incubation setup may have an immediate impact on the $\mathrm{CO}_{2}$ efflux rate by shortening the oxygen supply to living tissues and potentially influencing the isotope composition of emitted $\mathrm{CO}_{2}$. We tested this effect using a system close to that described in Werner et al. (2007). Entire mature sun leaves and twigs were sampled from the top of the canopy of three oaks and three beeches at the end of summer. Each sample was immediately inserted into a $50-\mathrm{ml}$ flask previously purged with either pure $\mathrm{N}_{2}$ or $\mathrm{CO}_{2}$-free air. Leaves $(n=44)$ and twigs $(n=20)$ were incubated in the dark under ambient temperature. In preliminary $\mathrm{CO}_{2}$ efflux rate measurements (data not shown), we determined that an incubation time between 10 and $25 \mathrm{~min}$ was required to collect enough emitted $\mathrm{CO}_{2}(800-900 \mathrm{ppm})$. The $\delta^{13} \mathrm{C}$ in air from the incubations was analysed by isotope ratio mass spectrometry (IRMS) as described below. These tests revealed no significant effect of the gaseous medium used, neither for beech or oak leaves nor for twigs $(p=0.72$ for leaves and $p=0.53$ for twigs, Fig. 1).

\subsubsection{Sampling of $\mathrm{CO}_{2}$ emitted by ecosystem components}

For $\mathrm{CO}_{2}$ emissions at the leaf and twig levels, these components were incubated as described above. Sun leaves and twigs from the tree canopy were sampled using a rifle. Leaves and twigs were immediately inserted into $50-\mathrm{ml}$ airtight syringes with valves (SGE, Australia) prepurged with pure $\mathrm{N}_{2}$. Air from the incubation syringe was then transferred into an empty syringe in Barbeau or into a 12$\mathrm{ml}$ Exetainer vial (Labco Ltd, High Wycombe, UK) in Hesse, according to the equipment available (see IRMS analyses below).

For trunk $\mathrm{CO}_{2}$ emissions, the trunk chamber was purged after each $E_{\mathrm{T}}$ measurement with $\mathrm{N}_{2}$ for 15 min until the $\mathrm{CO}_{2}$ concentration dropped to near $0 \mathrm{ppm}$. Then, outlet and inlet tubes of the chamber were connected to allow the

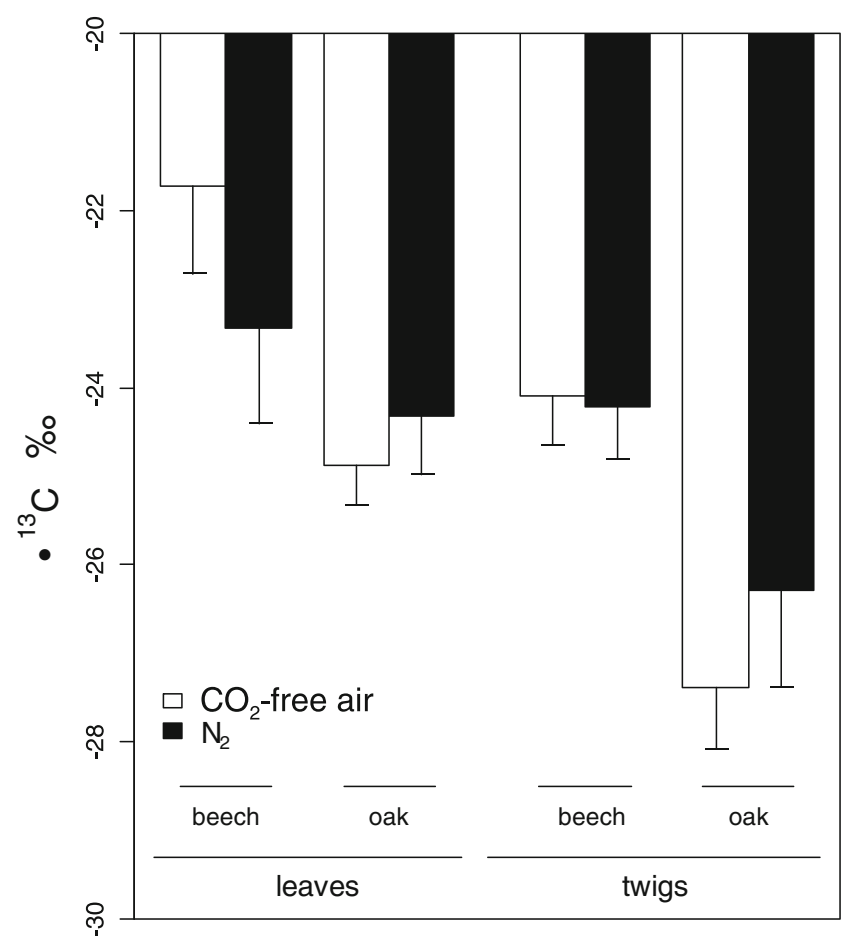

Fig. 1 Mean values of $\delta^{13} \mathrm{C}_{\mathrm{E}}$ measured for leaves and twigs of oak and beech incubated after flushing with $\mathrm{CO}_{2}$-free air (white) or $\mathrm{N}_{2}$ (black). Error bars represent standard errors of the mean. $n$ (leaf) $=27$ for oak and 17 for beech, and $n$ (twig) $=10$ for oak and 10 for beech 
accumulation of $\mathrm{CO}_{2}$ emitted by the trunk. After an increase of 700-800 ppm (during approximately $10 \mathrm{~min}$ in summer and $90 \mathrm{~min}$ in winter), the air in the chamber headspace, containing $\mathrm{CO}_{2}$ originating only from $E_{\mathrm{T}}$, was sampled using a $50-\mathrm{ml}$ syringe and analysed by IRMS. Again, this $\mathrm{N}_{2}$ flushing approach gave the same results as that using a $\mathrm{CO}_{2}$ free-air flush or estimating the $\delta^{13} \mathrm{C}$ of emitted $\mathrm{CO}_{2}$ with the Keeling plot method (Damesin et al. 2005).

For $\mathrm{CO}_{2}$ emitted by soil, the Keeling plot method (Keeling 1958) was applied to determine the $\delta^{13} \mathrm{C}_{\mathrm{E}}$ of $E_{\mathrm{S}}$ (Chemidlin Prévost-Bouré et al. 2009). The sampling setup consisted of 50-ml airtight syringes in Barbeau, or a homemade sampling device by-passing the Li-6200 air circuit (see Ngao et al. 2005 for details) in Hesse. After each $E_{\mathrm{S}}$ measurement, $\mathrm{CO}_{2}$ concentration was allowed to increase again within the closed system. During this increase, five air samples were taken at steps of 50-100 ppm within a 400 $1000 \mathrm{ppm}$ range inside Exetainer vials or 50-ml syringe and analysed by IRMS. From the Keeling plots, the $\delta^{13} \mathrm{C}_{\mathrm{ES}}$ for each collar was estimated using the ordinary least square regression model (Zobitz et al. 2007). $\delta^{13} \mathrm{C}_{\mathrm{ES}}$ was determined as the intercept of the linear regression between the inverse of the $\mathrm{CO}_{2}$ concentration and the $\delta^{13} \mathrm{C}$ of the air samples. $\delta^{13} \mathrm{C}_{\mathrm{ES}}$ values having a standard error $>5 \%$ of the estimated value were discarded.

\subsection{Sampling of plant and soil material for isotopic analysis}

At both sites and for each campaign, trunk phloem samples of the four trees were taken using a core borer $(0.5 \mathrm{~cm}$ diameter) at the chamber level or up to $30 \mathrm{~cm}$ above. Leaves and twigs used for the incubations and phloem samples were lyophilised and powdered using a ball mill (Type MM200, Retsch, Haan, Germany). Four soil cores (0-15 cm depth and $1.2 \mathrm{~cm}$ diameter) were sampled about $15 \mathrm{~cm}$ away from each collar. Soil samples did not include litter or roots.

\subsection{IRMS analyses}

To maintain airtight conditions, gas-filled syringes were processed within $12 \mathrm{~h}$ by laboratories close to the sites. Gas samples from the Barbeau were analysed with a NA1500 elemental analyser (Carlo Erba, Milan, Italy) coupled to a VG Optima IRMS (Fison, Villeurbanne, France), as described by Maunoury et al. (2007). Those from Hesse were injected into a gas purification device (Gas-Bench II, ThermoFinnigan, Bremen, Germany) coupled to a Delta S IRMS (ThermoFinnigan, Bremen, Germany). All solid samples were analysed with the NA-1500/IRMS setup.

All $\delta^{13} \mathrm{C}$ values were expressed relative to the Vienna Pee Dee Belemnite international standard. Different laboratory working standards (glutamic acid, $-28.06 \%$ for organic matter samples; air with $500 \mathrm{mmolmol}^{-1}$ of $\mathrm{CO}_{2},-53.10 \%$ for air samples) were measured after each group of 12 samples to correct for any offset of the IRMS. The precision for isotopic measurements was $\pm 0.2 \%$, based on repeated measurements of the laboratory working standards. Both IRMS systems were inter-calibrated for gas analyses using the same reference gas as above, revealing a discrepancy of $0.7 \%$ that was removed to the values measured at Hesse to have comparable values between both sites.

\subsection{Statistical analysis}

Pearson's correlation coefficients were calculated between $\delta^{13} \mathrm{C}_{\mathrm{E}}$ of each component and climatic data or $\mathrm{CO}_{2}$ efflux rates solely at Barbeau where measurements were more frequent. All climatic variables from the measurement day and the day before were tested.

Pearson correlations were also established between $\delta^{13} \mathrm{C}_{\mathrm{E}}$ of different components. Non-parametric Kruskal-Wallis rank sum tests should reveal differences among components at each site, and during the two main phenological periods, followed by Mann-Whitney tests to compare one component to another.

A one-way ANOVA was applied to compare $\delta^{13} \mathrm{C}_{\mathrm{E}}$ measurements in the incubation tests with $\mathrm{N}_{2}$ or $\mathrm{CO}_{2}$-free air flushings.

All analyses were performed using Statistica (version 7, Statsoft Inc., USA) and R 2.11.1 (R development core team 2010).

\section{Results}

\section{$3.1 \mathrm{CO}_{2}$ efflux rates}

At both sites, the trunk $\mathrm{CO}_{2}$ efflux $E_{\mathrm{T}}$ showed a pronounced seasonal evolution and ranged from 10 (April) to 130 (June) $\mu \mathrm{mol} \mathrm{CO}_{2} \mathrm{~m}^{-3}$ of living tissue ${ }^{-1}$ in Barbeau (Fig. 2a), and from 10 (March) to 88 (July) $\mu \mathrm{mol} \mathrm{CO}_{2} \mathrm{~m}^{-3}$ of living tissues ${ }^{-1}$ in Hesse (Fig. 2b). Variations of soil $\mathrm{CO}_{2}$ efflux were also marked, especially in Barbeau where $E_{\mathrm{S}}$ ranged from 0.7 (November) to 5.1 (July) $\mu \mathrm{mol} \mathrm{CO} \mathrm{CO}_{2}^{-2} \mathrm{~s}^{-1}$. In Hesse, it ranged from 0.7 (March) to 1.8 (September) $\mu \mathrm{mol}$ $\mathrm{CO}_{2} \mathrm{~m}^{-2} \mathrm{~s}^{-1}$ but summer efflux data, which are assumed to be highest, are missing. The maximum observed values of trunk and soil $\mathrm{CO}_{2}$ efflux at Barbeau (Fig. 2a) occurred during the trunk growth period when air and soil temperatures were high (Fig. 3). The lowest $\mathrm{CO}_{2}$ efflux rates occurred during winter.

\subsection{Carbon isotope composition of emitted $\mathrm{CO}_{2}$}

In oak forest, the carbon isotope composition of leaves $\left(\delta^{13} \mathrm{C}_{\mathrm{EL}}\right)$ showed the largest seasonal variations $(4.6 \%$, 


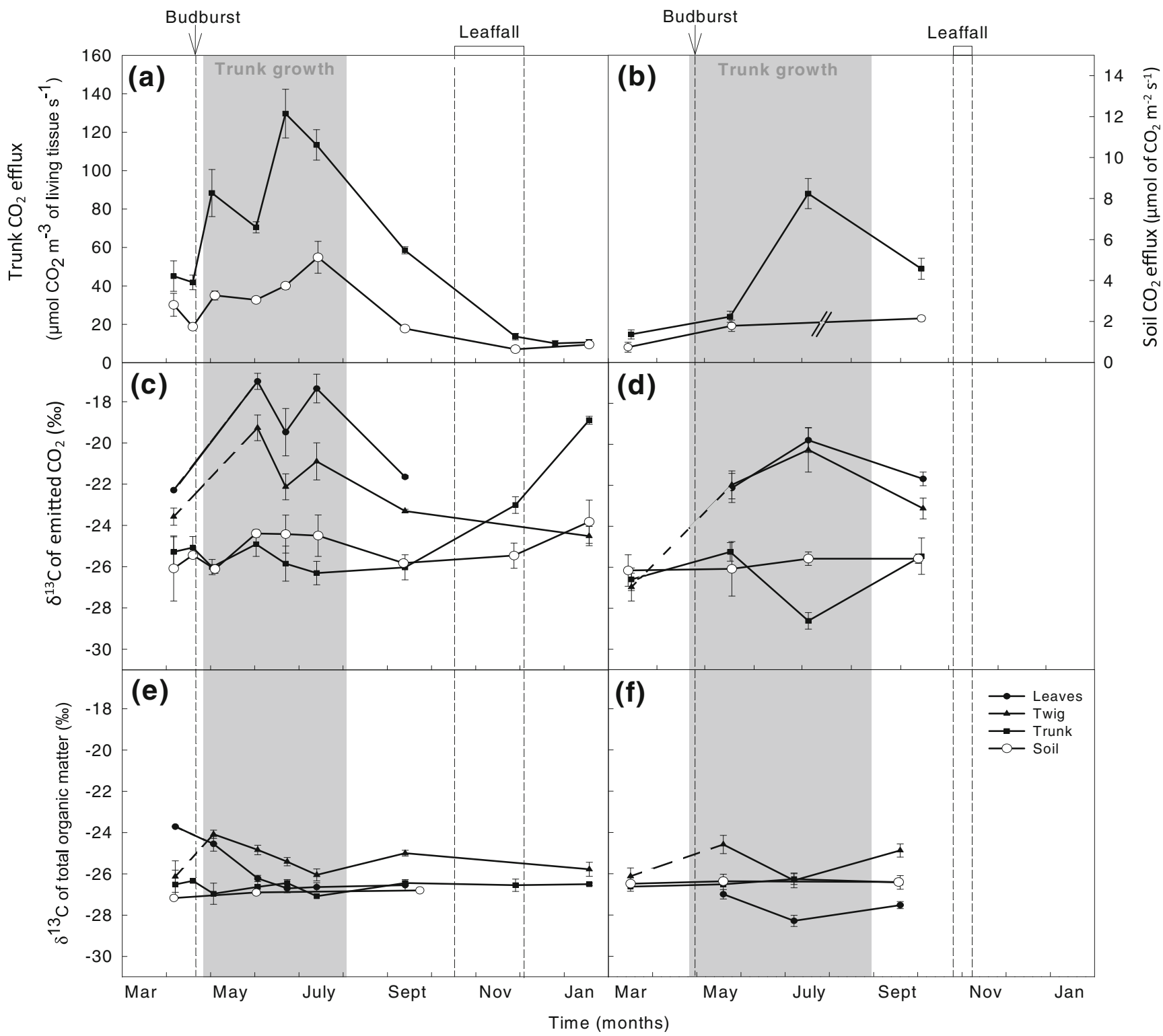

Fig. 2 Seasonal changes in trunk and soil respiration rate in Barbeau (oak forest) (a) and Hesse (beech forest) (b), in $\delta^{13} \mathrm{C}$ of emitted $\mathrm{CO}_{2}$ in Barbeau (c) and in Hesse (d), and in $\delta^{13} \mathrm{C}$ of total organic matter in Barbeau (e) and in Hesse (f), of leaf (filled circles), twig (filled triangles), trunk (filled squares) and total soil (open circles). Vertical

Fig. 2c). It was always higher than $\delta^{13} \mathrm{C}$ of $\mathrm{CO}_{2}$ emitted by buds in spring, i.e. the first measurement before budburst $(-22.3 \%)$. It increased during the whole growing season, with a small decrease in June and then decreased from September onwards. $\delta^{13} \mathrm{C}_{\mathrm{EL}}$ showed a similar pattern in Hesse albeit at a smaller observed range $(2.3 \%$ ) and lower values (Fig. 2d).

At both sites, $\delta^{13} \mathrm{C}_{\mathrm{E}}$ of twigs $\left(\delta^{13} \mathrm{C}_{\mathrm{ETG}}\right)$ clearly increased between budburst and May (Fig. 2c, d). In September, the values were near those before budburst for oak or those in dashed lines delimitate the budburst date and the leaf fall period. Before budburst, $\delta{ }^{13} \mathrm{C}_{\mathrm{E}}$ and $\delta{ }^{13} \mathrm{C}_{\mathrm{OM}}$ of leaves and twigs were measured on buds and previous year-twig. The trunk growth period is indicated in gray. Error bars represent standard errors of the mean

May for beech. During the trunk growth period, the $\delta^{13} \mathrm{C}_{\mathrm{ET}}$ was lower than the $\delta^{13} \mathrm{C}_{\mathrm{E}}$ of the two canopy components at both sites (Fig. 2c, d). In Barbeau, $\delta^{13} \mathrm{C}_{\mathrm{ET}}$ increased during winter and reached a maximum of $-18.9 \%$ in January 2006 (Fig. 2c).

Soil $\delta^{13} \mathrm{C}_{\mathrm{ES}}$ was rather similar at both sites, and seasonal variations were low (Fig. 2c, d). $E_{\mathrm{S}}$ and $\delta^{13} \mathrm{C}_{\mathrm{ES}}$ were not correlated (Table 2).

In Barbeau, $\delta{ }^{13} \mathrm{C}_{\mathrm{ETG}}$ was not related to any climatic variable, whereas $\delta^{13} \mathrm{C}_{\mathrm{EL}}$ was related to soil moisture 


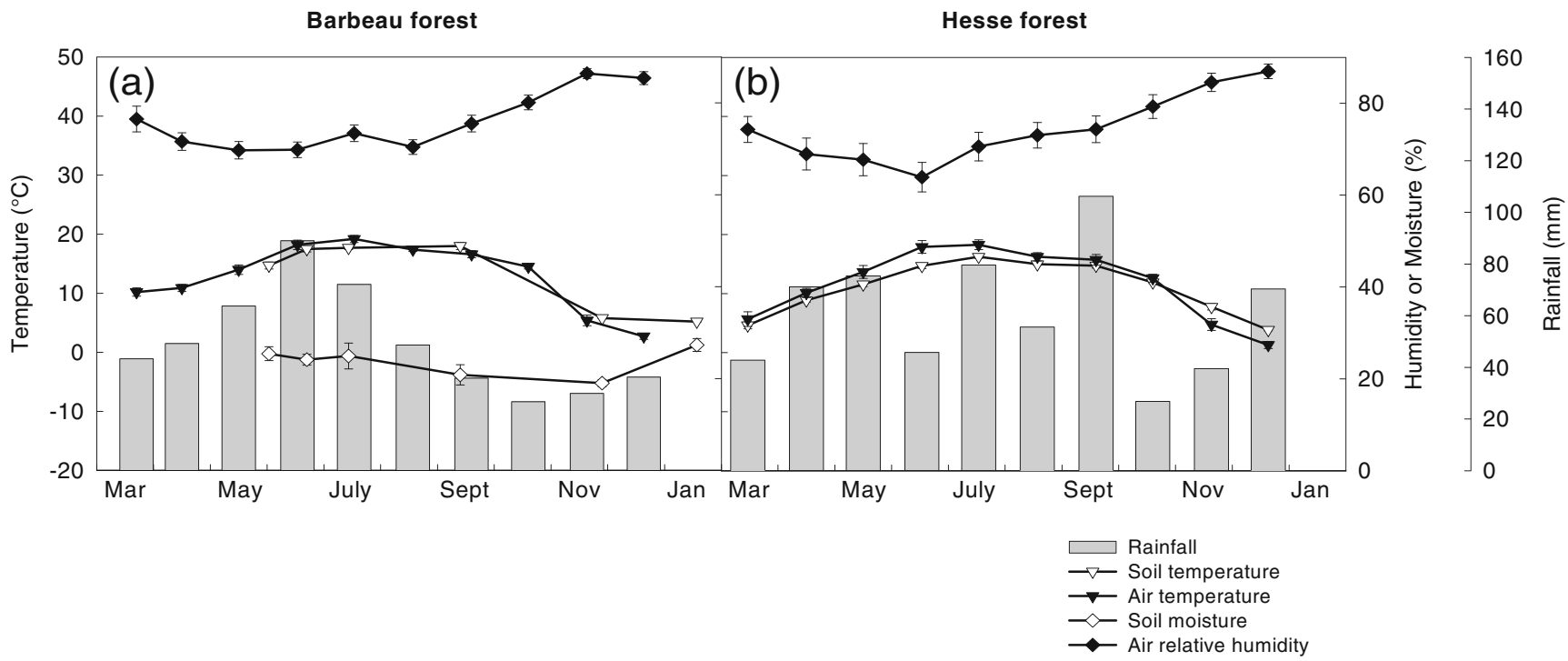

Fig. 3 Seasonal changes in rainfall (gray histogram), soil (open triangles) and air (filled triangles) temperature, soil moisture (open diamonds) and air relative humidity (filled diamonds), in Barbeau (oak forest) (a) and Hesse (beech forest) (b). Error bars represent standard errors of the mean

( $p=0.041$, Table 2) and $\delta^{13} \mathrm{C}_{\mathrm{ET}}$ was related to air and soil temperature ( $p=0.011$ and $p=0.012$, Table 2 ) and vapour pressure deficit $(p=0.033) . \delta^{13} \mathrm{C}_{\mathrm{ES}}$ values were only related to soil moisture $(p=0.006)$. Moreover, $\delta^{13} \mathrm{C}_{\mathrm{ET}}$ was negatively related to $E_{\mathrm{T}}$ and to $E_{\mathrm{S}}(r=-0.715 ; p=0.030$ and $r=-0.667 ; p=0.050$, respectively, Table 2 ). If only the values from the leafy period were kept, correlations between $\delta^{13} \mathrm{C}_{\mathrm{EL}}$ and $\delta^{13} \mathrm{C}_{\mathrm{ETG}}(r=0.955 ; p=0.011), \delta^{13} \mathrm{C}_{\mathrm{ES}}(r=0.917$; $p=0.029)$ and soil moisture $(r=0.960 ; p=0.041)$, and between $\delta^{13} \mathrm{C}_{\mathrm{ES}}$ and soil moisture $(r=0.966 ; p=0.034)$ were remaining.

From May to September (leafy period), $\delta^{13} \mathrm{C}_{\mathrm{E}}$ exhibited a vertical zonation in both ecosystems, revealing significant differences between components (Kruskal-Wallis ANOVA, $p<0.001$ for each site, Fig. 4). $\delta^{13} \mathrm{C}_{\mathrm{EL}}$ values were globally the highest, and $\delta^{13} \mathrm{C}_{\mathrm{ETG}}$ values were lower in Barbeau ( $p=$ $0.003)$ but not in Hesse $(p=0.380) . \delta^{13} C_{\mathrm{ETG}}$ values were always higher than those of trunk ( $p=0.001$, both systems) and soil ( $p=0.001$ in Barbeau and $p=0.002$ in Hesse). At both sites, $\delta{ }^{13} \mathrm{C}_{\mathrm{ET}}$ and $\delta^{13} \mathrm{C}_{\mathrm{ES}}$ values were not significantly different $(p=0.07$ in Barbeau and $p=0.16$ in Hesse) and represented the lowest $\delta^{13} \mathrm{C}_{\mathrm{E}}$ values.

During leaf fall (October) and winter (January), the vertical zonation was not maintained (Fig. 4). This period was characterised by an increase in $\delta^{13} \mathrm{C}_{\mathrm{ET}}$.

\section{$3.3 \delta^{13} \mathrm{C}$ of total organic matter}

In contrast to $\delta^{13} \mathrm{C}_{\mathrm{E}}, \delta^{13} \mathrm{C}$ of total organic matter $\left(\delta^{13} \mathrm{C}_{\mathrm{OM}}\right)$ showed weak temporal variations. At both sites, the most

Table 2 Pearson's correlation coefficient $(r)$ matrix between carbon isotope signatures of emitted $\mathrm{CO}_{2}$ in leaves, twigs, trunk, soil and soil and climatic conditions in oak forest or $\delta^{13} \mathrm{C}_{\mathrm{E}}$ of leaves, twigs, trunk and soil

\begin{tabular}{|c|c|c|c|c|c|c|c|c|c|c|}
\hline & Instant $T_{\text {air }}$ & VPD & Instant $T_{\text {soil }}$ & $H_{\mathrm{v} \text { soil }}$ & $E_{\mathrm{T}}$ & $E_{\mathrm{S}}$ & $\delta^{13} \mathrm{C}_{\mathrm{EL}}$ & $\delta^{13} \mathrm{C}_{\mathrm{ETG}}$ & $\delta^{13} \mathrm{C}_{\mathrm{ET}}$ & $\delta^{13} \mathrm{C}_{\mathrm{ES}}$ \\
\hline \multirow[t]{2}{*}{$\delta^{13} \mathrm{C}_{\mathrm{EL}}$} & ns & ns & $\mathrm{ns}$ & 0.960 & ns & ns & & 0.955 & ns & 0.917 \\
\hline & $p=0.853$ & $p=0.611$ & $p=0.316$ & $p=0.041$ & $p=0.334$ & $p=0.220$ & & $p=0.011$ & $p=0.953$ & $p=0.029$ \\
\hline \multirow{2}{*}{$\delta^{13} \mathrm{C}_{\mathrm{ETG}}$} & ns & ns & ns & ns & ns & ns & 0.955 & & ns & ns \\
\hline & $p=0.438$ & $p=0.373$ & $p=0.370$ & $p=0.953$ & $p=0.228$ & $p=0.156$ & $p=0.011$ & & $p=0.301$ & $p=0.625$ \\
\hline \multirow[t]{2}{*}{$\delta \delta^{13} \mathrm{C}_{\mathrm{ET}}$} & -0.789 & -0.708 & -0.909 & $\mathrm{~ns}$ & -0.715 & -0.667 & ns & ns & & ns \\
\hline & $p=0.011$ & $p=0.033$ & $p=0.012$ & $p=0.527$ & $p=0.030$ & $p=0.050$ & $p=0.953$ & $p=0.301$ & & $p=0.174$ \\
\hline \multirow[t]{2}{*}{$\delta^{13} \mathrm{C}_{\mathrm{ES}}$} & $\mathrm{ns}$ & ns & ns & 0.934 & ns & $\mathrm{ns}$ & 0.917 & ns & ns & \\
\hline & $p=0.817$ & $p=0.940$ & $p=0.702$ & $p=0.006$ & $p=0.755$ & $p=0.759$ & $p=0.029$ & $p=0.625$ & $p=0.174$ & \\
\hline
\end{tabular}

Only significant $r$ values are presented $(p<0.05)$

Instant $T_{\text {air }}$ and Instant $T_{\text {soil }}$ air and soil instantaneous temperature during measurements $\left({ }^{\circ} \mathrm{C}\right) ; V P D$ daily mean vapour pressure deficit (mBar) during the day of measurement; $H_{v}$ soil $(\%)$ soil volumetric moisture 
Fig. 4 Mean values ( \pm standard errors of the mean) of $\delta^{13} \mathrm{C}_{\mathrm{E}}$ (bold) and $\delta^{13} \mathrm{C}_{\mathrm{OM}}$ (italic) observed for each component (leaf, twig, trunk and soil) during the leafy period and winter, in Barbeau (oak forest) (left) and Hesse (beech forest) (right)

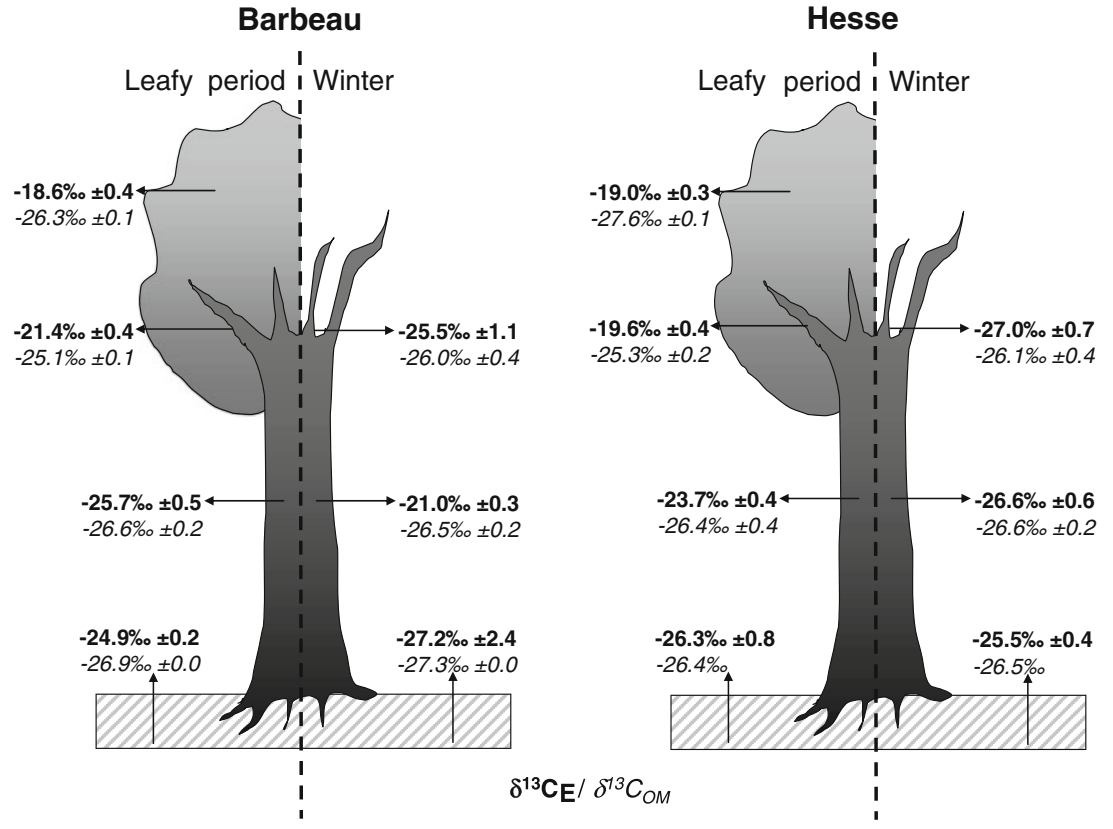

pronounced variations occurred in leaves and twigs with a slight decrease in July and a slight increase towards September (Fig. 2e, f). Variations in $\delta^{13} \mathrm{C}_{\text {OMT }}$ during the year were very narrow, with the same annual average of $-26.5 \%$ for the two forests (Fig. 2e, f). $\delta^{13} \mathrm{C}_{\mathrm{OMS}}$ values were stable and averaged $-27.01 \% \pm 0.06$ in Barbeau and $-26.21 \%$ o \pm 0.08 in Hesse.

When comparing organic matter to $\mathrm{CO}_{2}$ efflux $\delta^{13} \mathrm{C}$, differences between $\delta^{13} \mathrm{C}_{\mathrm{EL}}$ and $\delta^{13} \mathrm{C}_{\mathrm{OML}}$ were up to $9.3 \%$ (Barbeau) and 8.5\% (Hesse). Differences between $\delta^{13} \mathrm{C}_{\mathrm{ETG}}$ and $\delta^{13} \mathrm{C}_{\mathrm{OMTG}}$ for oak and beech were lower, with maxima of 5.6 and $6.1 \%$, respectively. During spring and summer, the difference between $\delta{ }^{13} \mathrm{C}_{\mathrm{ET}}$ and $\delta^{13} \mathrm{C}_{\mathrm{OMT}}$ was maximum $1.7 \%$ (Barbeau) and ranged between -2.4 and $1.3 \%$ (Hesse). After leaf fall in Barbeau, this difference reached values as high as 7.6\% in January. Differences between $\delta^{13} \mathrm{C}_{\mathrm{ES}}$ and $\delta^{13} \mathrm{C}_{\mathrm{OMS}}$ were always positive in Barbeau (1.0-2.5\%) but could be negative in Hesse (-1.6-1.0\%o.).

Finally, the differences in $\delta^{13} \mathrm{C}_{\mathrm{OM}}$ between organs were lower compared to those for $\delta^{13} \mathrm{C}_{\mathrm{E}}$. Even if $\delta^{13} \mathrm{C}_{\mathrm{OMTG}}$ was generally less negative than the $\delta^{13} \mathrm{C}_{\mathrm{OM}}$ of other components, no stable vertical zonation was apparent (Fig. 4).

\section{Discussion}

\subsection{Incubation methods for leaf and twig in the field}

Field protocols to collect $\mathrm{CO}_{2}$ efflux from tissue at the top of the canopy showed that $\delta^{13} \mathrm{C}_{\mathrm{E}}$ of attached leaves was similar to that of detached ones (Prater et al. 2005). Furthermore, an in-tube incubation method using $\mathrm{CO}_{2}$-free air flushes had been validated for $\delta^{13} \mathrm{C}_{\mathrm{E}}$ measurements and showed no difference to online gas exchange measurement (Werner et al. 2007). Here, we complete the methods debate on which approaches are compatible to field conditions, by testing two variants of tissue incubation with $\mathrm{CO}_{2}$-free air or $\mathrm{N}_{2}$ flushes. Our results clearly demonstrate that the different gases used do not change the measured $\delta^{13} \mathrm{C}_{\mathrm{E}}$ of leaves or twigs. Tissue incubation in vials previously flushed with $\mathrm{N}_{2}$ or $\mathrm{CO}_{2}$-free air can thus be used in the field to sample the emitted $\mathrm{CO}_{2}$ from current-year branches.

\subsection{Vertical zonation of $\delta^{13} \mathrm{C}_{\mathrm{E}}$ from canopy to soil} during the leafy period

In both forests, our measured $\delta{ }^{13} \mathrm{C}_{\mathrm{E}}$ values were comparable to those obtained for leaves in deciduous (Hymus et al. 2005) or coniferous forests (Prater et al. 2005), twigs (Damesin and Lelarge 2003), trunks (Damesin et al. 2005; Maunoury et al. 2007; Kuptz et al. 2011) and soil of deciduous forests (Ngao et al. 2005), coniferous forests (Ekblad et al. 2005) or rainforests (Buchmann et al. 1997).

We revealed that during the leafy period, $\delta{ }^{13} \mathrm{C}_{\mathrm{E}}$ values significantly differed among the ecosystem components, overall decreasing from the top of the canopy to the soil (Fig. 4). We observed this zonation at both sites, two different deciduous tree forests in distinct climatic conditions. Interestingly, no such zonation was found by Kuptz et al. (2011) in spruce and beech forests during the leafy period.

When there was a difference in $\delta^{13} \mathrm{C}_{\mathrm{E}}$ between twigs and leaves, it systematically consisted of a ${ }^{13} \mathrm{C}$ impoverishment of the $\mathrm{CO}_{2}$ emitted by twigs relative to leaves. This difference cannot be explained by differences in substrate $\delta^{13} \mathrm{C}$ because leaves have generally a significantly lower $\delta^{13} \mathrm{C}$ for starch and soluble sugars than twigs (Damesin and Lelarge 2003; 
Eglin et al. 2009). The gap between $\delta^{13} \mathrm{C}_{\mathrm{EL}}$ and $\delta^{13} \mathrm{C}_{\mathrm{ETG}}$ might be related to a difference in the balance of $\mathrm{CO}_{2}$ released by either pyruvate decarboxylation (resulting in ${ }^{13} \mathrm{C}$-enriched $\mathrm{CO}_{2}$ ) or by the Krebs cycle (resulting in ${ }^{13} \mathrm{C}$ depleted $\mathrm{CO}_{2}$, Tcherkez et al. 2003; Gessler et al. 2009).

The main hypotheses explaining differences in $\delta^{13} \mathrm{C}_{\mathrm{E}}$ between twigs and trunks are (1) an isotope discrimination during the assimilate transport in the phloem along twigs and trunk (Damesin and Lelarge 2003; Gessler et al. 2007), (2) changes in PEPc activity (Gessler et al. 2009; Kuptz et al. 2011), known to discriminate against ${ }^{12} \mathrm{C}$ during carbon fixation (Cernusak et al. 2009), (3) or a substantial contribution of belowground-evolved $\mathrm{CO}_{2}$ brought by the xylem sap stream to the upper part of the tree, i.e., in the trunk (Aubrey and Teskey 2009; Grossiord et al. 2012). Other processes may contribute to the ${ }^{13} \mathrm{C}$ impoverishment in trunk compared to twigs, especially the progressive mixing along metabolite translocation from sun and shade leaves via twigs to trunk (Eglin et al. 2010). It will be interesting to address in future studies in more detail the reasons for the differential isotope discrimination in twigs and trunk found in our study.

Comparable values of isotope composition of $\mathrm{CO}_{2}$ efflux in trunk and soil may be explained by the coupling of both components via $\mathrm{C}$ assimilates. Carbon substrates are rapidly transferred in broadleaved species from trunk to roots and via root exudates also to soil microorganisms (Dannoura et al. 2011; Epron et al. 2011). The comparable values for trunk and soil also suggest that contrary to substrate translocations from leaves to twigs, there is no apparent isotope discrimination during carbon translocation from trunk to soil.

\subsection{Seasonal variations in $\delta^{13} \mathrm{C}_{\mathrm{E}}$}

Seasonal ranges of emitted $\mathrm{CO}_{2} \delta^{13} \mathrm{C}$ were in agreement with ranges previously observed for beech leaves (Eglin et al. 2009), beech twigs (Damesin and Lelarge 2003), oak trunks (Maunoury et al. 2007) and hardwood forest soil (Mortazavi et al. 2005; Marron et al. 2009). Our maximum $\delta^{13} C_{E}$ values of leaves and twigs have been obtained during summer, in agreement with $\delta^{13} \mathrm{C}_{\mathrm{E}}$ of a coniferous forest ecosystem (Bowling et al. 2002; Mortazavi et al. 2005) but oppositely to $\delta^{13} \mathrm{C}_{\mathrm{E}}$ of a deciduous forest ecosystem (Mortazavi et al. 2005).

$\delta^{13} C_{\mathrm{E}}$ seasonal variations in leaves might be related to changes in respiratory substrate $\delta^{13} \mathrm{C}$ due to variable ${ }^{13} \mathrm{C}$ discrimination during $\mathrm{C}$ assimilation. The latter is itself linked to environmental conditions like soil moisture (Mortazavi et al. 2005). The correlation between $\delta^{13} \mathrm{C}_{\mathrm{EL}}$ and $\delta^{13} \mathrm{C}_{\mathrm{ETG}}$ (Table 2) suggests that $\delta^{13} \mathrm{C}_{\mathrm{ETG}}$ variability is linked to the same mechanisms as that of $\delta^{13} \mathrm{C}_{\mathrm{EL}}$. The increase in $\delta^{13} \mathrm{C}_{\mathrm{ET}}$ in winter might be explained by a switch of respiratory substrates from photosynthesis-derived sugars (lower $\delta^{13} \mathrm{C}$ ) during the leafy period to stored carbohydrates, i.e. starch with higher $\delta^{13} \mathrm{C}$, in the dormancy period as suggested before (Maunoury et al. 2007; Kuptz et al. 2011). Another explanation for these winter values is that, during winter time, transpiration is null and $\delta^{13} \mathrm{CE}_{\mathrm{T}}$ was no more influenced by a possible contribution of belowgroundevolved $\mathrm{CO}_{2}$. Surprisingly, we did not observe any increase in $\delta^{13} \mathrm{C}_{\mathrm{E}}$ for twigs, which, like trunks, probably use starch as main respiratory substrate. This unexpected difference between trunk and twig $\delta^{13} \mathrm{C}_{\mathrm{E}}$ may be explained by a metabolic discrepancy such as, e.g. differences in PEPc activity, during winter. Correlations between $\delta^{13} \mathrm{C}_{\mathrm{ET}}$ and $E_{\mathrm{T}}$ or air temperature have already been observed by Maunoury et al. (2007) in the same oak forest, with comparable correlation coefficients, suggesting that the respiration rate, which is influenced by air temperature, affects $\delta^{13} \mathrm{C}_{\mathrm{ET}}$.

During the leafy period, respiratory substrates are partially derived from $\mathrm{C}$ recently assimilated by leaves and transported by the phloem towards the trunk base and roots (Dannoura et al. 2011; Epron et al. 2011) and may finally end up via root exudates as organic matter in the soil. Such a substrate similarity between trunk and soil may result in $\delta^{13} C_{E S}$ values close to those measured for trunk during the leafy period. In contrast, during winter, a lack $\mathrm{C}$ assimilation lowers dramatically this recent $\mathrm{C}$ source for soil respiration, while trunk stored compounds with higher $\delta^{13} \mathrm{C}$ values supply substrates for $E_{\mathrm{T}}$. Furthermore, carbon supplies to the soil via root exudates are much lower or nil during winter. In addition, the heterotrophic component, i.e. microbial respiration, contributes more to the soil $\mathrm{CO}_{2}$ efflux and to $\delta^{13} C_{E S}$ than during the leafy period (Epron et al. 2001). This decoupling between trunk and soil respiratory substrate pools therefore may explain the significant differences in $\delta^{13} \mathrm{C}_{\mathrm{E}}$ of both components in winter.

At the soil and ecosystem level, temporal variations of $\delta^{13} \mathrm{C}_{\mathrm{E}}$ have been explained by environmental conditions with or without time lag (from 1 to 10 days) before measurement (e.g. Bowling et al. 2002; Ekblad et al. 2005; Marron et al. 2009). The present study showed a differential impact of environmental conditions on the $\delta^{13} \mathrm{C}_{\mathrm{E}}$ of the different components studied., Specifically, in contrast to other studies, we found no correlation between $\delta^{13} \mathrm{C}_{\mathrm{EL}}$ or $\delta^{13} \mathrm{C}_{\mathrm{ETG}}$ and climate (Mc Dowell et al. 2004; Mortazavi et al. 2005), which might be explained by the lower measurement frequency in our study. Yet, we found several correlations of environmental factors with $\delta^{13} \mathrm{C}_{\mathrm{ET}}$, suggesting that the trunk data integrate the overall climate effect on the tree. This argument can be supported by the facts that (1) a time lag exists for substrate transport in phloem from leaves to soil (Barnard et al. 2007) and (2) a progressive mixing of several different substrates (e.g. recent vs. stored compounds, top vs. bottom of tree canopy) along this $\mathrm{C}$ translocation. 
Lastly, the general enrichment of $\delta^{13} \mathrm{C}_{\mathrm{E}}$ in comparison with $\delta^{13} \mathrm{C}_{\mathrm{OM}}$ has been classically highlighted in previous studies (Damesin and Lelarge 2003; Klumpp et al. 2005; Maunoury et al. 2007). Our results show a mismatch between the $\delta^{13} \mathrm{C}_{\mathrm{E}}$ of each component and $\delta^{13} \mathrm{C}_{\mathrm{OM}}$ of the mature leaf, but these discrepancies were not stable throughout the year. Thus, our results invalidate the hypothesis of Bowling et al. (2008) that bulk leaf $\delta^{13} \mathrm{C}$ can be used as a reference value to predict differences between $\delta^{13} \mathrm{C}_{\mathrm{E}}$ and $\delta^{13} \mathrm{C}_{\mathrm{OM}}$ of plant components and ecosystem.

\section{Conclusion}

Our study highlights isotopic differences of $\mathrm{CO}_{2}$ emitted by the top (sun leaves and twigs) and the bottom of the forest (trunk base and soil) both with regard to higher $\delta^{13} \mathrm{C}$ values during the leafy period (higher at the top) and of seasonal dynamics (higher at the top). Variations in substrate $\delta^{13} \mathrm{C}$ (via the use of stored compounds or a mixing effect) might be the major-but not the only-explanation for these differences. Our study confirmed that $\delta^{13} \mathrm{C}_{\text {of }} \mathrm{CO}_{2}$ emitted by the forest components cannot be deduced from the $\delta^{13} \mathrm{C}$ of the total organic matter of the component, or from $\mathrm{CO}_{2}$ efflux intensity. Nowadays, high frequency measurements by tunable diode laser spectroscopy allow the analysis of temporal dynamics in $\delta^{13} C_{E}$ (Marron et al. 2009), especially during winter time, and offer thus better possibilities to understand inherent variability its link to metabolic processes.

Acknowledgements The authors are grateful to the Office National des Forêts, especially M. Bénard, for facilitating experimental work at Barbeau. We acknowledge N. Bréda (INRA Nancy, France) for trunk growth measurements at Hesse. The platform Métabolisme-Métabolome of the IFR87 is acknowledged for the isotope measurements. We are grateful to M. Danger and X. Raynaud for valuable discussions on the manuscript and to E. M. Gross for revising the manuscript. We thank two anonymous reviewers and the editor for their helpful comments and improvements to the manuscript.

Funding This research was funded by the French projects 'Ministère délégué à la recherche-ACI Jeunes Chercheurs' (no. JC10009) and 'Programme National ACI/FNS ECCO, PNBC' (convention no. 0429 FNS) and by the ESE laboratory thanks to funds from Paris-Sud University and CNRS.

\section{References}

Aubrey DP, Teskey RO (2009) Root-derived $\mathrm{CO}_{2}$ efflux via xylem stream rivals soil $\mathrm{CO}_{2}$ efflux. New Phytol 184:35-40

Barnard RL, Salmon Y, Kodama N, Sörgel K, Holst J, Rennenberg H, Gessler A, Buchmann N (2007) Evaporative enrichment and time lags between $\delta^{18} \mathrm{O}$ of leaf water and organic pools in a pine stand. Plant Cell Environ 30:539-550
Bowling D, Mc Dowell N, Bond B, Law B, Ehleringer J (2002) ${ }^{13} \mathrm{C}$ content of ecosystem respiration is linked to precipitation and vapor pressure deficit. Oecologia 131:113-124

Bowling D, Pataki D, Randerson J (2008) Carbon isotopes in terrestrial ecosystem pools and $\mathrm{CO}_{2}$ fluxes. New Phytol 178:24-40

Buchmann N, Guel JM, Barigah TS, Ehleringer JR (1997) Interseasonal comparison of $\mathrm{CO} 2$ concentrations, isotopic composition and carbon dynamics in an Amazonian rainforest (French Guiana). Oecologia 110:120-131

Cernusak LA, Tcherkez G, Keitel C, Cornwell WK, Santiago LS, Knohl A, Barbour MM, Williams DG, Reich PB, Ellsworth DS, Dawson TE, Griffiths HG, Farquhar GD, Wright IJ (2009) Why are non-photosynthetic tissues generally ${ }^{13} \mathrm{C}$ enriched compared with leaves in $\mathrm{C}_{3}$ plants? Review and synthesis of current hypotheses. Funct Plant Biol 36:199-213

Ceschia E, Damesin C, Lebaube S, Pontailler J, Dufrene E (2002) Spatial and seasonal variations in stem respiration of beech trees (Fagus sylvatica). Ann For Sci 59:801-812

Chemidlin Prévost-Bouré N, Ngao J, Berveiller D, Bonal D, Damesin C, Dufrêne E, Lata JC, Le Dantec V, Longdoz B, Ponton S, Soudani K, Epron D (2009) Root exclusion through trenching does not affect the isotopic composition of soil $\mathrm{CO}_{2}$ efflux. Plant Soil 319:1-13

Damesin C, Lelarge C (2003) Carbon isotope composition of currentyear shoots from Fagus sylvatica in relation to growth, respiration and use of reserves. Plant Cell Environ 26:207-219

Damesin C, Barbaroux C, Berveiller D, Lelarge C, Chaves M, Maguas C, Maia R, Pontailler JY (2005) The carbon isotope composition of $\mathrm{CO}_{2}$ respired by trunks: comparison of four sampling methods. Rapid Commun Mass Spectrom 19:369-374

Dannoura M, Maillard P, Fresneau C, Plain C, Berveiller D, Gerant D, Chipeaux C, Bosc A, Ngao J, Damesin C, Loustau D, Epron D (2011) In situ assessment of the velocity of carbon transfer by tracing ${ }^{13} \mathrm{C}$ in trunk $\mathrm{CO}_{2}$ efflux after pulse labelling: variations among tree species and seasons. New Phytol 190:181-192

Eglin T, Francois C, Michelot A, Delpierre N, Damesin C (2010) Linking intra-seasonal variations in climate and tree-ring $813 \mathrm{C}$ : A functional modelling approach. Ecol Model 221:1779-1797

Eglin T, Fresneau C, Lelarge-Trouverie C, François C, Damesin C (2009) Leaf and twig $\delta^{13} \mathrm{C}$ during growth in relation to biochemical composition and respired $\mathrm{CO}_{2}$. Tree Physiol 29:777-788

Ekblad A, Bostrom B, Holm A, Comstedt D (2005) Forest soil respiration rate and $\delta^{13} \mathrm{C}$ is regulated by recent above ground weather conditions. Oecologia 143:136-142

Epron D, Le Dantec V, Dufrene E, Granier A (2001) Seasonal dynamics of soil carbon dioxide efflux and stimulated rhizosphere respiration in a beech forest. Tree Physiol 21:145-152

Epron D, Ngao J, Dannoura M, Bakker MR, Zeller B, Bazot S, Bosc A, Plain C, Lata JC, Priault P, Barthes L, Loustau D (2011) Seasonal variations of belowground carbon transfer assessed by in situ ${ }^{13} \mathrm{CO}_{2}$ pulse labelling of trees. Biogeosciences 8:1153-1168

Gessler A, Keitel C, Kodama N, Weston C, Winters AJ, Keith H, Grice $\mathrm{K}$, Leuning R, Farquhar GD (2007) $\delta^{13} \mathrm{C}$ of organic matter transported from the leaves to the roots in Eucalyptus delegatensis: short-term variations and relation to respired $\mathrm{CO}_{2}$. Funct Plant Biol 34:692-706

Gessler A, Tcherkez G, Karyanto O, Keitel C, Ferrio JP, Ghashghaie J, Kreuzwieser J, Farquhar GD (2009) On the metabolic origin of the carbon isotope composition of $\mathrm{CO}_{2}$ evolved from darkened light-adapted leaves in Ricinus communis. New Phytol 181:374-386

Grossiord C, Mareschal L, Epron D (2012) Transpiration alters the contribution of autotrophic and heterotrophic components of soil CO2 efflux. New Phytol 194:647-653. doi:10.1111/j.14698137.2012.04102.x

Hemming D et al (2005) Pan-European $\delta^{13} \mathrm{C}$ values of air and organic matter from forest ecosystems. Glob Chang Biol 11:1065-1093 
Hymus G, Maseyk K, Valentini R, Yakir D (2005) Large daily variation in ${ }^{13} \mathrm{C}$ enrichment of leaf respired $\mathrm{CO}_{2}$ in two Quercus forest canopies. New Phytol 167:377-384

Keeling CD (1958) The concentration and isotopic abundances of atmospheric carbon dioxide in rural areas. Geochim Cosmochim Ac 13:322-334

Klumpp K, Schaufele R, Lotscher M, Lattanzi F, Feneis W, Schnyder $\mathrm{H}$ (2005) C-isotope composition of $\mathrm{CO}_{2}$ respired by shoots and roots: fractionation during dark respiration? Plant Cell Environ 28:241-250

Kodama $\mathrm{N}$ et al (2008) Temporal dynamics of the carbon isotope composition in a Pinus sylvestris stand: from newly assimilated organic carbon to respired carbon dioxide. Oecologia 156:737750

Kuptz D, Matyssek R, Grams TEE (2011) Seasonal dynamics in the stable carbon isotope composition $\left(\delta^{13} \mathrm{C}\right)$ from non-leafy branch, trunk and coarse root $\mathrm{CO}_{2}$ efflux of adult deciduous (Fagus sylvatica) and evergreen (Picea abies) trees. Plant Cell Environ 34:363-373

Marron N, Plain C, Longdoz B, Epron D (2009) Seasonal and daily time course of the ${ }^{13} \mathrm{C}$ composition in soil $\mathrm{CO}_{2}$ efflux recorded with a tunable diode laser spectrophotometer (TDLS). Plant Soil 318:137-151

Maunoury F, Berveiller D, Lelarge C, Pontailler J, Vanbostal L, Damesin C (2007) Seasonal, daily and diurnal variations in the stable carbon isotope composition of carbon dioxide respired by tree trunks in a deciduous oak forest. Oecologia 151:268-279

Mc Dowell N, Bowling DR, Bond BJ, Irvine J, Law BE, Anthoni P, Ehleringer JR (2004) Response of the carbon isotopic content of ecosystem, leaf, and soil respiration to meteorological and physiological driving factors in a Pinus ponderosa ecosystem. Global biogeochem cy 18:1-12

Mortazavi B, Chanton J, Prater J, Oishi A, Oren R, Katul G (2005) Temporal variability in ${ }^{13} \mathrm{C}$ of respired $\mathrm{CO}_{2}$ in a pine and a hardwood forest subject to similar climatic conditions. Oecologia 142:57-69

Ngao J, Epron D, Brechet C, Granier A (2005) Estimating the contribution of leaf litter decomposition to soil $\mathrm{CO}_{2}$ efflux in a beech forest using ${ }^{13} \mathrm{C}$-depleted litter. Glob Chang Biol 11:1768-1776

Ngao J, Longdoz B, Perrin D, Vincent G, Epron D, Le Dantec V, Soudani K, Aubinet M, Willm F, Granier A (2006) Crosscalibration functions for soil $\mathrm{CO}_{2}$ efflux measurment systems. Ann For Sci 63:477-484

Prater J, Mortazavi B, Chanton J (2005) Diurnal variation of the $\delta^{13} \mathrm{C}$ of pine needle respired $\mathrm{CO}_{2}$ evolved in darkness. Plant Cell Environ 29:202-211

Tcherkez G, Nogues S, Bleton J, Cornic G, Badeck F, Ghashghaie J (2003) Metabolic origin of carbon isotope composition of leaf dark-respired $\mathrm{CO}_{2}$ in french bean. Plant Physiol 131:237-244

Ubierna N, Marshall JD, Cernusak LA (2009) A new method to measure carbon isotope composition of $\mathrm{CO}_{2}$ respired by trees: stem $\mathrm{CO}_{2}$ equilibration. Funct Ecol 23:1050-1058

Werner C, Hasenbein N, Maia R, Beyschlag W, Maguas C (2007) Evaluating high time-resolved changes in carbon isotope ratio of respired $\mathrm{CO}_{2}$ by a rapid in-tube incubation technique. Rapid Commun Mass Spectrom 21:1352-1360

Zobitz J, Burns S, Ogee J, Reichstein M, Bowling D (2007) Partitioning net ecosystem exchange of $\mathrm{CO}_{2}$ : a comparison of a Bayesian/isotope approach to environmental regression methods. J Geophys Res 112:G03013 